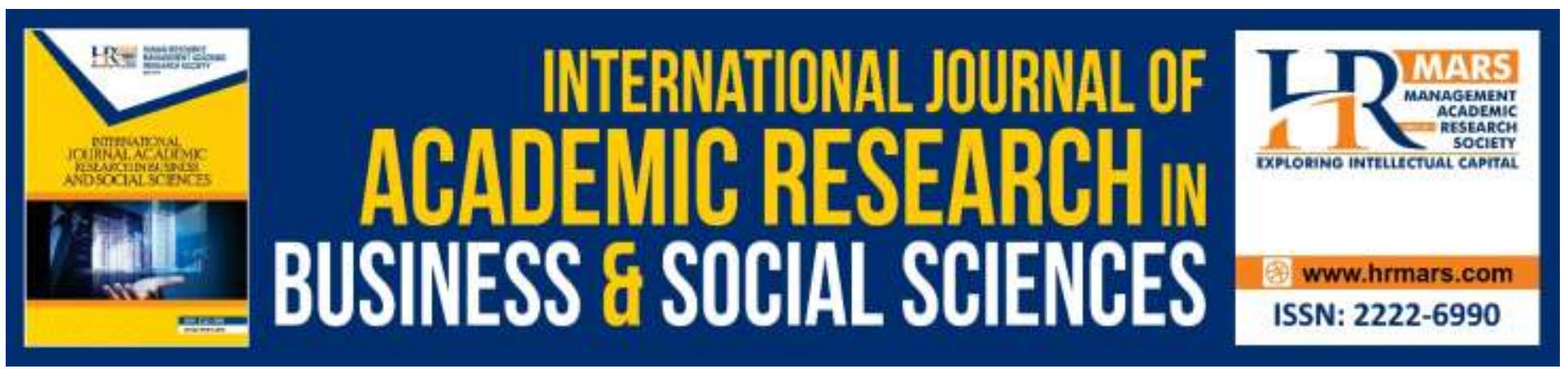

\title{
Communicative Language Tasks to Enhance Young Learners' Communicative Competence
}

Theresa Chermi Legak, Wahiza Wahi

To Link this Article: http://dx.doi.org/10.6007/IJARBSS/v10-i6/7308

DOI:10.6007/IJARBSS/v10-i6/7308

Received: 21 April 2020, Revised: 24 May 2020, Accepted: 03 June 2020

Published Online: 28 June 2020

In-Text Citation: (Legak \& Wahi, 2020)

To Cite this Article: Legak, T. C., \& Wahi, W. (2020). Communicative Language Tasks to Enhance Young Learners' Communicative Competence. International Journal of Academic Research in Business and Social Sciences, 10(6), 377-390.

\section{Copyright: (c) 2020 The Author(s)}

Published by Human Resource Management Academic Research Society (www.hrmars.com)

This article is published under the Creative Commons Attribution (CC BY 4.0) license. Anyone may reproduce, distribute, translate and create derivative works of this article (for both commercial and non-commercial purposes), subject to full attribution to the original publication and authors. The full terms of this license may be seen

at: http://creativecommons.org/licences/by/4.0/legalcode

Vol. 10, No. 6, 2020, Pg. 377 - 390

http://hrmars.com/index.php/pages/detail/IJARBSS

JOURNAL HOMEPAGE

Full Terms \& Conditions of access and use can be found at http://hrmars.com/index.php/pages/detail/publication-ethics 


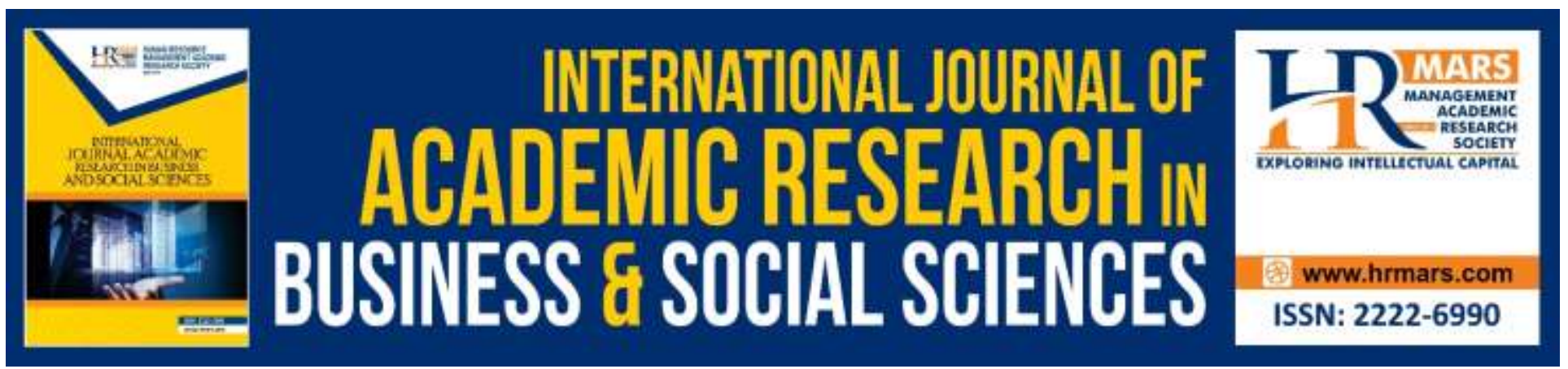

\title{
Communicative Language Tasks to Enhance Young Learners' Communicative Competence
}

\author{
Theresa Chermi Legak \\ Faculty of Education, Universiti Kebangsaan Malaysia \\ Email: chermilegak@gmail.com \\ Wahiza Wahi \\ Pusat Citra Universiti, Universiti Kebangsaan Malaysia \\ Email:wawa@ukm.edu.my
}

\begin{abstract}
The Malaysian curriculum reform in 2011 for English as a Second Language (ESL) was designed with the intent to set a national curriculum system that is on par with international standards by adopting CEFR into the ESL classroom. However, challenges arose when rural primary school learners were found to have lower proficiency level. Therefore, this study investigated the impact of communicative language tasks on rural primary school learners' communicative competence in Julau, Sarawak, Malaysia. This study also explored the learners' perspective towards the communicative language tasks in developing their communicative competence. Informed by the qualitative approach of data collection, this study employed pre-test, post-test and individual interviews with ten research participants selected through purposive sampling. Findings from this study disclosed that the CEFRaligned communicative language tasks enhanced the learners' grammatical, sociolinguistic, discourse and strategic communicative competence. The findings also revealed that the learners have developed intrinsic motivation and interest to learn English using the communicative language tasks. Keywords: CEFR, ESL, Communicative Competence, Communicative Language Tasks, Rural Primary School Learners.

\section{Introduction}

A paradigm shift in learning, especially in the $21^{\text {st }}$ century, has made traditional teaching method, chalk - and - talk approach, no longer relevant in the classroom. Instead, a more learner-centered approach is deemed more suitable where teachers are strongly encouraged to foster the development of critical, creative, collaborative and communicative skills (more synonymously known as the 4Cs) among learners particularly the young ones. With regard to language learning, a framework was introduced based on an action-oriented approach to language learning and use
\end{abstract}


INTERNATIONAL JOURNAL OF ACADEMIC RESEARCH IN BUSINESS AND SOCIAL SCIENCES Vol. 10, No. 6, June, 2020, E-ISSN: 2222-6990 @ 2020 HRMARS

known as the Common European Framework of Reference or CEFR. It is a comprehensive descriptive scheme that offers a tool for reflecting language learning, teaching as well as language use.

CEFR-aligned English as a Second Language (ESL) curriculum in Malaysia which combines formative and summative assessment that allows teachers to monitor and record learners' progress in their learning and achievement was introduced (Ong, 2011; Othman, Salleh \& Norani, 2013) as highlighted in the Malaysian Education Blueprint 2013-2025 to put more emphasis on the skills of 4Cs - communicative, collaborative, critical thinking and creativity (Sidhu, Kaur \& Lee, 2018). Moreover, the Malaysian curriculum reform has adopted the CEFR levels as a guidance for curriculum development and also a tool for assessment by using "can do" descriptors to specify the learning outcome, a learning focus, or simply and assessment task (Little, 2013).

The implementation of CEFR-aligned curriculum became even more challenging when rural primary school learners in Malaysia were found to have low level of proficiency in English as compared to those enrolling in urban schools (Hazita, 2016; Abdul Rahim \&Lee, 2017; Rosli \& Edwin, 2018) which can be due to certain factors such as limited exposure to the language and limited opportunities to use the language (Rajasekaran \& Anburaj, 2015). To date, many rural schools are challenged with the demands of modern education (Arnold, Newman, Gaddy \& Dean, 2005), and with CEFR coming into the curriculum system, it hinders interactive learning from taking place as the CEFRaligned textbooks contain audio-visual language tasks such as audio recordings, interactive videos and language games.

Furthermore, most rural school learners were found to be passive learners. A study by Lim, Yunus and Embi (2017) noted that the learners depended highly on their teachers to acquire the language hence leading to poor communicative skills in English. Effective language learning, according to Lightbown and Spada (2013), takes place best in immersion situations, where apart from using the language for academic purposes it is also used outside the academic setting for communicative purposes. Hence, it is crucial to create opportunities for the learners to use the language for communicative purpose beyond the classroom by engaging them in formal, structured contexts, and informal, less structured contexts (Ministry of Education Malaysia, 2015).

In terms of the content of the CEFR-aligned textbook, the main textbook materials for primary schools were imported by the Ministry of Education Cambridge University Press (Super Minds) for Year 1 and 2 (Aziz, Rashid \& Zainudin, 2018), where language tasks mainly comprise of unfamiliar jargons and foreign elements. In producing effective language learners, Highmore (2002) suggested that social competence and cultural identity are interrelated and are both necessary in socialization for the purpose of meaning-making at routine level; this is not only restricted to classroom context alone but also with close family members and ethnic community. In support to that, Ur (2008) explained that interesting topics that are also meaningful allow the learners to be motivated to communicate with their friends and express themselves freely.

The study reported in this paper intended to achieve the following objectives;

i. to examine the impact of the communicative language tasks (based on the CEFR-aligned curriculum) on the rural primary school learners' communicative competence.

ii. to explore the learners' perspective on the communicative language tasks.

This study was guided by the following research questions:

iii. What are the impacts of communicative language tasks towards the rural primary school learners' communicative competence?

iv. What is the learners' perspective on the communicative language tasks? 
To elucidate the above, this paper begins by describing the concepts underpinning this study which embrace the Communicative Competence Framework and Common European Framework of Reference (CEFR). This is followed by explaining the methodology employed by the study. Next, the findings describe the impacts of communicative language tasks towards the learners' communicative competence and present their overall perspectives on the communicative language tasks. Finally, the paper ends with a brief consideration of the pedagogical implications of the findings of the study.

\section{Literature Review}

\section{Communicative Competence Framework}

Wild and Sage (2006) highlighted that children's communicative competence is very important as the determiner of their performance in school, which can be achieved through the role of language for social construction of knowledge in a variety of educational contexts (Rojas-Drummong, Mazon, Fernandez \& Wegerif, 2006). A study by Yen (2013) reflected that communicative language activities in English lessons were able to provide a learning context that exposed the learners to the language as they participated actively and communicated with each other. In another similar study, Fazil, Nor and Halim (2018) found that learners showed excitement and interest to participate in communicative activities, however, their lack of English proficiency hindered them from being able to communicate and collaborate effectively using the target language. As a result, they switched into their first language (L1) to interact with their teachers and peers during group works or role play activities.

The concept that underpinned this study, which is the Communicative Competence Framework, was first developed by Canale and Swain (1980) and later revised in 1983 (Fauziah, 2015). It includes four main components; (1) grammatical competence - sentence-level semantics, morphology, syntax and phonology, (2) sociolinguistic competence - appropriateness of register, vocabulary and politeness norms, (3) discourse competence - cohesion and coherence, and (4) strategic competence - verbal and non-verbal strategies as speakers used to achieve a desired end result (Canale \& Swain, 1980; Fauziah, 2015). It highlights the learners' ability to use the target language in meaningful and authentic situations, hence a natural setting for language learning.

Goullier (2007) stated that the Council of Europe has outlined suitable and goal-oriented communicative language tasks that can be implemented in order to achieve the target CEFR level; this study particularly observed the skills intended for level A1. Hence, the tasks intended for communicative competence have been adapted into this study to achieve the learning outcomes for each component, as illustrated in Table 1. The tasks set to achieve the specific learning outcomes were coded from LO1 until LO6 to highlight the findings of this study in the later part of this paper. 
INTERNATIONAL JOURNAL OF ACADEMIC RESEARCH IN BUSINESS AND SOCIAL SCIENCES Vol. 10, No. 6, June, 2020, E-ISSN: 2222-6990 @ 2020 HRMARS

Table 1. Communicative Language Tasks in the CEFR-aligned Curriculum to Achieve the Learning Outcomes in the Framework

\begin{tabular}{|c|c|c|c|}
\hline $\begin{array}{l}\text { Components of } \\
\text { Framework }\end{array}$ & Learning Outcomes & $\begin{array}{c}\text { Communicative Language Tasks in } \\
\text { CEFR-aligned Curriculum }\end{array}$ & Task Code \\
\hline \multirow[t]{2}{*}{$\begin{array}{l}\text { Grammatical } \\
\text { competence }\end{array}$} & $\begin{array}{l}\text { Able to master the linguistic } \\
\text { code }\end{array}$ & $\begin{array}{l}\text { Can give simple expression } \\
\text { about personal details and needs } \\
\text { of a concrete type }\end{array}$ & LO1 \\
\hline & $\begin{array}{l}\text { Able to use knowledge and } \\
\text { skills required for } \\
\text { understanding and } \\
\text { expressing the literal } \\
\text { meaning of utterances }\end{array}$ & $\begin{array}{l}\text { Can repeat and explain } \\
\text { meanings of isolated words and } \\
\text { phrases related to particular } \\
\text { concrete situations }\end{array}$ & LO2 \\
\hline $\begin{array}{l}\text { Sociolinguistic } \\
\text { competence }\end{array}$ & $\begin{array}{l}\text { Able to use language } \\
\text { correctly in specific } \\
\text { situations }\end{array}$ & $\begin{array}{l}\text { Can establish basic social contact } \\
\text { by using the simplest everyday } \\
\text { polite forms of greetings, } \\
\text { farewells, and introductions; } \\
\text { saying please, thank you, sorry } \\
\text { etc }\end{array}$ & LO3 \\
\hline $\begin{array}{l}\text { Discourse } \\
\text { competence }\end{array}$ & $\begin{array}{l}\text { Able to use the language } \\
\text { fluently }\end{array}$ & $\begin{array}{l}\text { Can link words or group of words } \\
\text { with very basic linear connectors } \\
\text { like 'and' and 'then' }\end{array}$ & LO4 \\
\hline $\begin{array}{l}\text { Strategic } \\
\text { competence }\end{array}$ & $\begin{array}{l}\text { Able to use verbal and non- } \\
\text { verbal strategies in } \\
\text { communication }\end{array}$ & $\begin{array}{l}\text { Can use simple techniques to } \\
\text { start, maintain or end a short } \\
\text { conversation }\end{array}$ & LO5 \\
\hline
\end{tabular}

\section{Common European Framework of Reference (CEFR)}

Nakatani (2012) conducted a study to test the effectiveness of communication strategies which is one of the features in the CEFR meant to improve learners' proficiency in communicative tasks. The study revealed that the success of learners is dependent on their active involvement in the activities throughout the strategy training period. Similarly, Nagai (2011) also found that conventional teaching method in Japan has shifted to a more learner-centered approach since the CEFR has been introduced into its education system, and that CEFR is able to promote independent learning; based on the 'can do' statements, learners can set their own learning goals and assess their learning independently by referring to them as guidelines. Naganuma (2010) also concurred that the 'can do' lists are able to help learners understand better and be more familiar with the levels of language ability set for each grade. As CEFR is an action-oriented based approach (North, 2007), it is reported that the positive impact of the CEFR-based instruction includes allowing learners to enjoy language activities, especially low proficiency learners, thus creating a sense of independence and boosting their confidence (Faez et. al., 2011).

In order to test whether CEFR-aligned curriculum fits into the Malaysian education context, Azli and Akmar (2019) in their study revealed that majority of teacher still preferred to use the conventional assessment methods and the study participants collectively agreed that they were dependent on textbook exercises as their main assessment tool. In another earlier study, Sidhu, Kaur 
and Lee (2018) revealed that a lot of teachers opted to use textbook exercises as the yardstick to evaluate their learners' ESL proficiency. Even so, teachers have positive attitude towards the CEFR framework but require more proper training for them to implement the assessments successfully in their classrooms. It is supported by Sidhu, Kaur and Chi (2018) who, in their study found that based on the data obtained from the surveys, interviews and document analysis from selected primary schools in Damansara, teachers do not possess adequate confidence and understanding of CEFRaligned SBA. Similar findings were also recorded in Othman, Salleh and Md. Noranin (2013) and in another similar study for secondary school teachers by Sidhu, Chan and Azleena (2011) thus affecting the implementation of CEFR in the ESL classroom.

\section{Methodology}

This study employed a qualitative approach of data collection through pre-test, post-test and interview. These methods were deemed relevant to achieve the objectives of this study. The communicative language tasks were selected with close reference to the English Language Education Reform in Malaysia: The Roadmap 2015-2025 (Ministry of Education Malaysia, 2015) after a careful consideration on its suitability to the 'can do' descriptors to achieve A1 level, as expected to be achieved by the learners at the end of Year Three (Ministry of Education Malaysia, 2015).

The sampling design used in this study was purposive sampling. Ten participants consisted of Year Three learners, aged 9 years old, and studying in a rural primary school in Julau, Sarawak were selected based on the preliminary data collection on the participants' current proficiency level by referring to their language portfolio for School-Based Assessment (SBA) from when they were in Year 1 and 2. These learners are of the Iban ethnic group whose mother tongue was the Iban language. Coming from a rural area with only gravel road access in Julau and with limited network coverage, the only exposure for English language is only within the one-hour English lesson in the classroom. From the preliminary data collection, it was found that all of the research participants were categorized as intermediate proficient user of ESL and thus were selected for the purpose of this study.

The instruments used in pre-test and post-test were distributed to the learners and it comprised of five communicative tasks as illustrated in Table 1 earlier. In between the pre-test and post-test, interventions in the form of communicative tasks suggested by the CEFR-aligned textbook were implemented in the English lessons such as information gaps, jigsaw, structured interviews, role plays, interactive language games, pair, and also group works. The tasks performed were evaluated based on a five-point scale descriptor; (1) very weak, (2) weak, (3) average, (4) good and (5) excellent by the teacher immediately after the lessons have been conducted. The results of the pre-test and post-test were then compared and illustrated in the findings session.

After the pre-test and post-test have been administered, a face-to-face interview was carried out with the learners to find out their perception on how CEFR's communicative language tasks impact their communicative competence. Considering the proficiency level of the research participants, vocabulary capacity and their age, the interview was conducted in Bahasa Iban (the participants' mother tongue) and was later transcribed to English. The interview session was recorded with the consent of the participants. The validity was determined using triangulation from different sources, meaning that the perspectives from different participants were taken into account to confirm the findings. The result of the interview was then analyzed using thematic content analysis 
INTERNATIONAL JOURNAL OF ACADEMIC RESEARCH IN BUSINESS AND SOCIAL SCIENCES Vol. 10, No. 6, June, 2020, E-ISSN: 2222-6990 @ 2020 HRMARS

method and coded into two themes; (1) interest and motivation to participate in learning and (2) response towards communicative language tasks.

\section{Results}

i) The impacts of communicative language tasks toward learners' communicative competence The results obtained from the pre-test and post-test clearly showed that communicative language tasks in the CEFR-aligned curriculum were successful in developing the learners' communicative competence in all four components of grammatical, sociolinguistic, discourse and strategic. A more in depth findings were illustrated in the following tables.

Table 2. Learners' Performance in Grammatical Component Task (LO1) in Pre-Test and Post-Test

\begin{tabular}{ccccccc}
\hline Communicative Tasks / & & \multicolumn{5}{c}{ Scale Descriptor (\%) } \\
\cline { 3 - 7 } Learning Outcomes & Test & $\begin{array}{c}\text { Very } \\
\text { Weak }\end{array}$ & Weak & Average & Good & Excellent \\
\hline \multirow{2}{*}{ LO1 } & Pre & 40 & 40 & 20 & 0 & 0 \\
\cline { 2 - 7 } & Post & 0 & 0 & 30 & 50 & 20 \\
\hline
\end{tabular}

Based on the result in Table 2 and Table 3, it is indicated that learners have shown a significant improvement in the grammatical competence component through the implementation of two communicative language tasks (LO1 and LO2) in the CEFR-aligned curriculum in the pre-test and posttest. The task intended for LO1 required the learners to be able to give simple expression about personal details and needs of a concrete type. The post-test result of LO1 showed that a majority of $70 \%$ of the learners managed to obtain score in both good and excellent range. Thus, it signifies that learners were able to master the linguistic code where they can give simple expression about personal details and needs of a concrete type. For example, the learners could use basic simple phrases and sentences such as My name is..., I'm nine years old, and I live in... to provide personal details, for example;

Question: What's your name?

Learner's response: My name is Camelia / I'm Camelia.

In the pre-test, they would only provide short answers as a response to the stimulus, for example;

Question: What's your name?

Learner's response: Camelia.

Table 3. Pupil's Performance in Grammatical Component Task (LO2) in Pre-Test and Post-Test

\begin{tabular}{|c|c|c|c|c|c|c|}
\hline \multirow{2}{*}{$\begin{array}{l}\text { Communicative Tasks } \\
\text { / Learning Outcomes }\end{array}$} & \multirow[b]{2}{*}{ Test } & \multicolumn{5}{|c|}{ Scale Descriptor (\%) } \\
\hline & & $\begin{array}{l}\text { Very } \\
\text { Weak }\end{array}$ & Weak & Average & Good & Excellent \\
\hline \multirow[t]{2}{*}{ LO2 } & Pre & 10 & 60 & 30 & 0 & 0 \\
\hline & Post & 0 & 0 & 10 & 60 & 30 \\
\hline
\end{tabular}


INTERNATIONAL JOURNAL OF ACADEMIC RESEARCH IN BUSINESS AND SOCIAL SCIENCES Vol. 10, No. 6, June, 2020, E-ISSN: 2222-6990 @ 2020 HRMARS

Similarly, the result portrayed in Table 3 also illuminated that $90 \%$ of the learners were able to use knowledge and skills required for understanding and expressing the literal meaning of utterances as they can repeat and explain meanings of isolated words and phrases related to particular concrete situations, indicating that they have achieved LO2 successfully. For example, the learners were able to complete a pair work matching activity successfully by matching words taken out from a reading text with their correct meaning, such as the word breakfast, homework, and shower.

Table 4. Learners' Performance in Sociolinguistic Component Task (LO3) in Pre-Test and Post-Test

\begin{tabular}{ccccccc}
\hline $\begin{array}{c}\text { Communicative Tasks / } \\
\text { Learning Outcomes }\end{array}$ & Test & \multicolumn{5}{c}{ Scale Descriptor (\%) } \\
\cline { 2 - 7 } & & $\begin{array}{c}\text { Very } \\
\text { Weak }\end{array}$ & Weak & Average & Good & Excellent \\
\hline LO3 & Pre & 30 & 50 & 20 & 0 & 0 \\
\cline { 2 - 7 } & Post & 0 & 0 & 20 & 50 & 30 \\
\hline
\end{tabular}

The result in Table 4 illuminated that in the post-test, learners have shown positive increment in sociolinguistic component of the communicative competence as $50 \%$ and $30 \%$ of the learners were respectively good and excellent in the correct use of language in specific situations. Simultaneously, it signifies that learners could establish basic social contact by using the simplest everyday polite forms of greetings, farewells, and introductions; for example, saying please, thank you and sorry.

Table 5. Learners' Performance in Discourse Component Task (LO4) in Pre-Test and Post-Test

\begin{tabular}{ccccccc}
\hline Communicative Tasks / & & \multicolumn{5}{c}{ Scale Descriptor (\%) } \\
\cline { 2 - 7 } Learning Outcomes & Test & $\begin{array}{c}\text { Very } \\
\text { Weak }\end{array}$ & Weak & Average & Good & Excellent \\
& LO4 & 20 & 70 & 10 & 0 & 0 \\
\cline { 2 - 7 } & Pre & 0 & 0 & 40 & 50 & 10 \\
\hline
\end{tabular}

As shown in Table 5, the post-test result showed a significant rise in terms of score as a combination of $60 \%$ managed to obtain good and excellent score, indicating that the discourse component task (LO4) enabled learners to link words or group of words with very basic linear connectors like 'and' and 'then', and thus acquiring fluency.

Table 6. Learners' Performance in Strategic Component Task (LO5) in Pre-Test and Post Test

\begin{tabular}{ccccccc}
\hline $\begin{array}{c}\text { Communicative Tasks / } \\
\text { Learning Outcomes }\end{array}$ & Test & \multicolumn{5}{c}{ Scale Descriptor (\%) } \\
\cline { 2 - 7 } & $\begin{array}{c}\text { Very } \\
\text { Weak }\end{array}$ & Weak & Average & Good & Excellent \\
\hline \multirow{2}{*}{ L05 } & Pre & 50 & 30 & 20 & 0 & 0 \\
\cline { 2 - 7 } & Post & 0 & 0 & 40 & 40 & 20 \\
\hline
\end{tabular}

Likewise, the learners also showed positive results in the strategic component task (LO5) as it can be seen in the post-test result in Table 6 that $40 \%$ and $20 \%$ of the learners obtained good and excellent scores in the task respectively. Hence, it means that they were able to use verbal and non- 
INTERNATIONAL JOURNAL OF ACADEMIC RESEARCH IN BUSINESS AND SOCIAL SCIENCES

Vol. 10, No. 6, June, 2020, E-ISSN: 2222-6990 @ 2020 HRMARS

verbal strategies in communication, such as using simple techniques to start, maintain or end a short conversation. For example, the learners managed to use suitable phrases for when they agree or disagree to a statement or situation such as Yes, I agree.. or No, I don't agree...

\section{ii) Learners' perception towards communicative language tasks and its significance in improving their communicative competence \\ Interest and motivation to participate in learning}

Based on the interview, most of the learners agreed the integration of communicative language tasks in the ESL lessons allowed them to have more autonomy in the activities, thus making them more eager to participate in learning. The responses given were generally positive, as illustrated in the following excerpts from the interview with different learners were gathered, analyzed and coded into a similar theme. Learners find the communicative language tasks interesting and these tasks boost their motivation to participate in learning as illustrated in the following remarks.

"I want to perform with my best friend....I'm not shy when she's with me..." (Learner 1)

\footnotetext{
"I always tell my mum what I learned in class.." (Learner 2)

“...I can say words like....and it makes me feel excited.." (Learner 6)

“..I cannot wait for teacher to come in and teach us..." (Learner 6)

"I like running in the class because it feels like PE class..." (Learner 9)
}

The above remarks showed that the communicative language tasks allowed them to interact not only with the teacher but also with their fellow friends, creating a fun and meaningful learning environment. Hence, the learners became interested in such activities, and active and encouraged participation from the teacher indirectly motivated them to get involved in learning.

Most of the learners were contented with the communicative language tasks. They have positive acceptance towards communicative language tasks and brought the learning home. These are evidenced from their expressions below:

"I remember this word with the action..." (Learner 2)

"I talked to the headmaster in English today.." (Learner 4)
“...I can talk to my friends in English now..the other day, we talked about..."
(Learner 8)

"I taught my mother how to say..." (Learner 10)

In regards to the learners' overall perspectives, the communicative language tasks implemented in the ESL lessons have gone beyond the classroom, meaning that the learning process 
INTERNATIONAL JOURNAL OF ACADEMIC RESEARCH IN BUSINESS AND SOCIAL SCIENCES

Vol. 10, No. 6, June, 2020, E-ISSN: 2222-6990 @ 2020 HRMARS

continued on when the learners were at home. It implies that natural learning was nurtured beyond classroom context as learners used the target language in authentic situations, for example, communicating with the school's headmaster and conversing with their parents at home. Thus, communicative language tasks helped learners to be independent in their own learning as they were able to use the language freely without feeling intimated or anxious of making mistakes.

\section{Discussions}

The findings illustrated in the pre-test and post-test have shown that communicative language tasks proved to be effective in improving rural primary school learners' communicative competence. In addition, the result from the interview reported that the learners were positive towards the use of communicative language tasks to help them acquire communicative competence.

The post-test result indicated that communicative language tasks allow learners to acquire all the components of communicative competence based on the framework proposed by Canale and Swain (1980) that are grammatical competence, sociolinguistic competence, discourse competence and strategic competence. Wild and Sage (2006) suggested that verbal exchanges are formative and through interaction with others, it provides exposure in daily communicative functions, thus explaining how learners acquire the four components of communicative competence. In an earlier study, Sage (2003) also noted that narrative exchanges help children to review and refine their thinking as it allows mental development. Moreover, children's communicative competence can be achieved through the role of language for social construction of knowledge in a variety of educational contexts (Wild \& Sage, 2006). Thus, communicative language tasks act as a way to express their thoughts and to give feedbacks through linguistic functions (Vygotsky, 1992; Piaget, 1983a, 1983b; Pinker, 2003).

Correspondingly, the interview results also portrayed that communicative language tasks helped to develop learners who have keen interest and motivation to participate in the learning, within and beyond the classroom context. The interview with the learners proved that they felt happy and excited to learn using communicative language tasks and interacted actively with their friends during ESL lessons. A study by Nakatani (2012) noted that communicative language strategies in such tasks allowed learners' communicative skills to be honed through its integration in his or her learning process. In the same vein, the learners' remarks indicated that the learning process occur within and beyond the classroom context, allowing natural and independent learning to happen. In addition to that, Nagai (2011) also claimed that the strategies written in the form of 'can do' statements were able to promote independent learning as learners can set their own learning goals conducts selfassessments.

Furthermore, the communicative language tasks designed in the CEFR-aligned curriculum were action-oriented based approach (North, 2007) and enabled learners to enjoy the language activities, especially low proficiency learners, thus creating a sense of independence and boosting their motivation. Additionally, Faez et. al. (2011) also noted that CEFR's communicative language tasks have been found to increase learners' intrinsic motivation towards their own learning, build self-confidence, encourage the use of authentic language in the classroom and provide an education setting that allows learner autonomy.

This study has provided some insights that show the needs to provide suitable interventions to help improve learners' proficiency level by boosting their interests and motivation to participate actively in language learning, thus creating a more natural and authentic setting for them to be able 
to use the language freely. Brown (1991) asserted that learners who have high intrinsic motivation are more likely to succeed in learning. When learners interact with each other in informal, lessstructured contexts, learning will naturally take place unconsciously as they experience a sense of achievement after completing a communicative task.

Larsen-Freeman (2000) stated that the integration of authentic materials into language activities will help create a variety of contexts for real world communication to take place. Additionally, it also helps to reduce artificiality of classroom learning, but rather bridging the gap with the real world setting. When this type of language learning occurs, learners would find the process of acquiring the language becomes clearer and in a more appropriate way.

The findings from this research illustrated that the learners' learning process does not happen within the classroom wall alone but also beyond the classroom, for example, at home. Hence, it is appropriate for learners to have adequate opportunities to practice the language in a more natural and authentic situations outside the classroom, such as in making or displaying school announcements, conducting school assemblies and co-curricular activities as extra communicative language tasks to perform.

\section{Conclusion}

Based on the study, the use of communicative language tasks in the CEFR-aligned curriculum has proven that learners' communicative competence can be improved. For further studies, the communicative tasks implemented can be adjusted based on the learners' proficiency level according to the CEFR descriptor to see their impacts towards pupils in different level. For example, researchers can plan more difficult and complex communicative tasks for pupils in $\mathrm{C} 1$ and $\mathrm{C} 2$ level, while giving simpler and easier language tasks to those in lower levels like A1 and A2 in order to make a comparison on their respective performance in relation to communicative competence.

The findings reported in this study also confirmed that concept illustrated in the Communicative Competence Framework has indeed taken place throughout the implementation of the communicative language tasks in the CEFR-aligned curriculum. The increments in score denoted in the post-test informed the researchers that there was a positive impact on the learners' performance implying that there is an inter-relation between the components of the framework with the communicative language tasks as suggested in the CEFR-aligned curriculum. Leung and Lewkowicz (2013) found that communicative competence framework works in which a speaker has to have a disposition to engage with others, meaning that they have to participate in communication whether in contexts where they need to cooperate to achieve understanding across languages and cultural practices. They further added that the key to achieve communicative sensibility is by providing a platform or task for learners to practice and develop their competence.

The impact of globalization and the global spread of the English language affirm the need to equip oneself with communicative language competence to be able to compete within a global economy, whilst enhancing one's national development. The results obtained in the pre-test and post-test have shown that through communicative language tasks, learners were able to acquire communicative competence, specifically in four components; grammatical, sociolinguistic, discourse and strategic. In addition, the result from interview also showed that these tasks also allowed learners to become more interested in language learning and have also developed intrinsic motivation as they became independent learners who applied their linguistic knowledge in both formal and informal situations. An earlier study by Butzkamm (2007) revealed that communicative language tasks focus 
on the actual content of the interactions between individuals, hence provide opportunities for participants to deliver 'real messages'. Thus, learners are able to use the language in a natural and authentic setting.

This study has shown that the communicative language tasks were able to improve the learners' communicative competence by looking at their acquisition on the four components of the Communicative Competence Framework. Furthermore, through this study policy makers and curriculum developers will be enlightened as to how CEFR-aligned curriculum fits in the rural school setting and what needs to be done to improve the curriculum to suit the reality of language acquisition and proficiency level among rural school English language learners. The results obtained from this study also illustrated suitable intervention to help improve learners' proficiency level based on the CEFR level descriptor by boosting their interests and motivation to participate actively in language learning, thus creating a more natural and authentic setting for them to be able to use the language freely. Multon, Brown and Lent (1991) asserted that learners who have high intrinsic motivation are more likely to succeed in learning. In addition, young learners will also be able to maintain their learning interest besides developing positive attitude towards learning (Wright, Betteridge \& Buckby, 1984). When learners interact with each other in informal, less-structured contexts, learning will naturally takes place unconsciously as they experience a sense of achievement after completing a communicative task.

The findings in this study also showed that communicative language tasks included in the CEFR-aligned curriculum encourage learners to practice language in interactive formats and be actively involved in comprehension, manipulation, production and interaction on the English language (Willis, 1996). Thus, learners have more opportunity to acquire the language in a natural, yet meaningful context. Larsen-Freeman (2000) stated that the integration of authentic materials into language activities will help create a variety of contexts for real world communication to take place. Additionally, it also helps to reduce artificiality of classroom learning, but rather bridging the gap with the real world setting. When this type of language learning occurs, learners would find the process of acquiring the language becomes clearer and in a more appropriate way.

With a proper and official assessment tool, these learning outcomes in the components can be integrated as one of the requirements to determine learners' proficiency level, that, including the 'can do' statements. Therefore, this assessment tool is crucial so that a valid and reliable CEFR-aligned primary school national exam can be implemented. However, the findings of this study may not be applicable to all rural primary school English language learners in Malaysia as the sample of this research was only exclusive to those who enroll in the selected rural school.

\section{Acknowledgement}

I would like to extend my gratitude and appreciation to my supervisor Dr Wahiza Wahi, senior lecturer at Pusat Citra Universiti Kebangsaan Malaysia, for the encouragement, wise comments and endless support throughout her guidance in the completion of this project paper. I am forever indebted for the academic advice which has developed my research skill.

I would also like to extend my gratitude towards all the research participants comprising of nine year old pupils whom I teach in Sekolah Kebangsaan Nanga Kedup, Julau, Sarawak, Malaysia, for your full cooperation and active participation in completing my project paper. 
INTERNATIONAL JOURNAL OF ACADEMIC RESEARCH IN BUSINESS AND SOCIAL SCIENCES

Vol. 10, No. 6, June, 2020, E-ISSN: 2222-6990 @ 2020 HRMARS

\section{References}

Arnold, M. L., Newman, J. H., Gaddy, B. B., \& Dean, C. B. (2005). A look at the condition of rural education research: Setting a direction for future research. Journal of Research in Rural Education, 20(6), 1-25.

Aziz, A. H. A. A., Ab Rashid, R., \& Zainudin, W. Z. W. (2018). The enactment of the Malaysian common European framework of reference (CEFR): National master trainer's reflection. Indonesian Journal of Applied Linguistics, 8(2), 409-417.

Azli, N., And Akmar, A. (2019). Implementation of CEFR-Aligned Assessment Tools in Malaysian ESL Classroom. Asia Proceedings of Social Sciences, 4(2), Pp.7-10.

Brown, H. D. (1987). Principles of Language Learning and Teaching. (2nd ed.). Englewood Cliffs, New Jersey: Prentice Hall.

Butzkamm, W. (2007). Native language skills as a foundation for foreign language learning. Transcending boundaries. Essays in honour of Gisela Hermann-Brennecke. Berlin: Lit Verlag, 71-85.

Canale, M., and Swain, M. (1980). The theoretical bases of communicative approaches to second language teaching and testing. Applied Linguistics, Vol. 1, No. 1, pp. 1-47

Faez, F., Majhanovich, S., Taylor, S. K., Smith, M., and Crowley, K. (2011). The power of “Can Do" statements: Teachers' perceptions of CEFR-informed instruction in French as a second language classrooms in Ontario. Canadian Journal of Applied Linguistics, 14(2), p.1.

Fauziati, E. (2015). A State of the Art of Communicative Competence Theory. Ahmad Dahlan Journal of English Studies (ADJES), 2(2).

Fazil, S. H. S. M., Nor, F. M., \& Halim, N. A. A. (2018). Issues in promoting Communicative Competence among Malaysian Primary School Students. International Journal of Academic Research in Business and Social Sciences, 8(8), 608-619.

Highmore, B. (2002). The everyday life and cultural theory. New York: Routledge

Goullier, F. (2007). Council of Europe tools for language teaching. Common European Framework and Portfolios. Paris: Didier.

Larsen-Freeman, D. (2000). Techniques and principles in language teaching. Oxford University.

Leung, C., \& Lewkowicz, J. (2013). Language communication and communicative competence: Aview from contemporary classrooms. Language and Education, 27(5), 398-414.

Lightbown, P. M., \& Spada, N. (2013). How Languages are learned ( $4^{\text {th }}$ ed). Oxford: Oxford University Press.

Little, D. (2007). The Common European Framework of Reference for Languages: Perspectives on the making of supranational language education policy. The Modern Language Journal, 91,645-655.

Ministry of Education Malaysia. (2015). English language education reform in Malaysia: The roadmap 2015-2025. (M. Orey, Ed.). Putrajaya: English Language Standards and Quality Council, Ministry of Education Malaysia.

Multon, K. D., Brown, S. D., \& Lent, R. W. (1991). Relation of self-efficacy beliefs to academic outcomes: A meta-analytic investigation. Journal of counseling psychology, 38(1), 30.

Nagai, N., and O'Dwyer, F. (2011). The actual and potential impacts of the CEFR on language education in Japan. Synergies Europe, 6, pp.141-152. 
INTERNATIONAL JOURNAL OF ACADEMIC RESEARCH IN BUSINESS AND SOCIAL SCIENCES

Vol. 10, No. 6, June, 2020, E-ISSN: 2222-6990 @ 2020 HRMARS

Naganuma, N. (2010). The Range and Triangulation of Can Do Statements in Japan. In: Schmidt, M.S., Naganuma, N., O’Dwyer, F., Imig, A., Sakai, K. (eds.), 2010. Can do statements in language education in Japan and beyond. Tokyo: Asahi Press, pp. 19-34.

Nakatani, Y. (2009). An interview study of English levels in international business contexts: An initial qualitative data analysis for CEFR-J Tokyo University of Science Kiyo, 42, 91-102.

Nakatani, Y. (2012). Exploring the implementation of the CEFR in Asian contexts: Focus on communication strategies. Procedia-Social and Behavioral Sciences, 46, pp.771-775.

Nordin, N. M., Ali, F. D. R., Zubir, S. I. S. S., \& Sadjirin, R. (2013). ESL learners reactions towards code switching in classroom settings. Procedia-Social and Behavioral Sciences, 90, 478-487.

North, B. (2007). The CEFR: Development, theoretical and practical issues. Babylonia, 1(07), pp.2229.

Othman, I., Salleh, N. M., \& Norani, N. A. M. (2013). The Implementation of school-based assessment in primary school standard curriculum. International Journal of Education and Research, 1(7), 1-10.

Pinker, S. (2003). El instinto del lenguaje. Madrid: Alianza Editorial.

Rajasekaran, C., and Anburaj, G. (2015). Ways of teaching English in rural areas. IOSR Journal of Humanities and Social Science, 20(2): 100-12.

Rojas-Drummond, S., Mazón, N., Fernández, M., and Wegerif, R. (2006). Explicit reasoning, creativity and co-construction in primary school children's collaborative activities. Thinking Skills and Creativity, 1(2), pp.84-94.

Sage, R. (2003). Lend us your ears: listen and learn. Stafford: Network Educational Press

Sidhu, G. K., Kaur, S., \& Chi, L. J. (2018). CEFR-aligned school-based assessment in the Malaysian primary ESL classroom. Indonesian Journal of Applied Linguistics, 8, 452- $463 . \quad$ doi: 10.17509/ijal.v8i2.13311

Sidhu, G. K., Chan, Y., \& Azleena, M. (2011). Teachers' knowledge and understanding of the Malaysian school-based oral English assessment. Malaysian Journal of Learning and Instruction, 8, 93115.

Ur, P. (2008). A Course in Language Teaching: Practice and Theory: Trainer's Handbook. Cambridge: Cambridge Teacher Training and Development.

Wilde, M. E., and Sage, R. (2007). Developing the communicative competence and narrative thinking of four and five year olds in educational settings. Early Child Development and Care, 177(6-7), pp.679-693.

Willis, J. (1996). A framework for task-based learning (Vol. 60). Harlow: Longman.

Wright, A., Betteridge, D., \& Buckby, M. (1984). Games for language learning (2nd ed.). Cambridge: Cambridge University Press.

Yen. H., W. (2013). Developing Taiwanese Elementary School Learners' EFL Communicative Competence through Communicative Language Activities. pp. 27-41. 